\title{
AKTIVITAS ENZIM PROTEASE DALAM LAMBUNG DAN USUS IKAN KERAPU MACAN SETELAH PEMBERIAN PAKAN
}

\author{
Muhamad Yamin ${ }^{*}$, Neltje N. Palinggi*), dan Rachmansyah*) \\ *) Balai Riset Perikanan Budidaya Air Payau, Maros
}

\begin{abstract}
ABSTRAK
Ikan kerapu macan (Epinephelus fuscoguttatus) adalah salah satu jenis ikan karnivora yang membutuhkan kadar protein tinggi dalam pakannya. Untuk meningkatkan efisiensi pakan dan mengoptimalkan pertumbuhan ikan perlu memperhatikan manajemen pakan. Salah satu hal yang perlu diperhatikan adalah aktivitas enzim protease di lambung dan usus ikan kerapu macan setelah pemberian pakan. Pengamatan yang dilakukan adalah aktivitas enzim protease dalam lambung dan usus ikan kerapu macan pada 12, 15, dan 18 jam setelah pemberian pakan. Dari hasil ini diperoleh nilai rata-rata aktivitas enzim protease dalam lambung ikan kerapu macan pada 12 dan 15 jam setelah pemberian pakan adalah $2,615 \mu / \mathrm{mL}$ dan $0,292 \mu / \mathrm{mL}$. Pada 18 jam setelah pemberian pakan, aktivitas enzim proteasenya tidak ada. Sedang nilai rata-rata aktivitas enzim protease dalam usus pada 12, 15, dan 18 jam setelah pemberian pakan adalah $7,45 \mu / \mathrm{mL} ; 6,08$ $\mu / \mathrm{mL}$; dan $5,03 \mu / \mathrm{mL}$. Hasil yang diperoleh menunjukkan bahwa aktivitas enzim protease di lambung dan usus menurun dengan semakin lamanya waktu setelah pemberian pakan
\end{abstract}

KATA KUNCI: Epinephelus fuscoguttatus, protease usus, protease lambung, aktivitas protease

\section{PENDAHULUAN}

Ikan kerapu macan (Epinephelus fuscoguttatus) merupakan salah satu ikan budidaya yang bernilai ekonomi cukup baik yakni berkisar antara Rp 50.000,--Rp 70.000,- per kilogram pada tingkat pembudidaya/ nelayan. Saat ini, kegiatan budidaya pembesaran ikan kerapu macan telah dikembangkan pada keramba jaring apung (KJA). Dalam kegiatan pembesaran di KJA, pakan merupakan salah satu komponen yang sangat menentukan keberhasilan. Selain itu, pakan memberikan kontribusi yang paling besar dalam kegiatan budidaya ikan yakni mencapai $60 \%$ dari total biaya produksi khususnya pada kegiatan budidaya intensif (Usman \& Palinggi, 2005).

Untuk mendapatkan keuntungan yang lebih besar maka manajemen pakan perlu diperhatikan sehingga dapat meningkatkan efisiensi dan mengoptimalkan pertumbuhan ikan. Ikan kerapu macan sebagai ikan karnivora cenderung membutuhkan pakan dengan konsentrasi protein yang tinggi yakni antara 45\%-50\% (Laining et al., 2003ab; Kabangnga et al., 2004). Pemahaman tentang sistem pencernaan protein di tubuh kerapu macan khususnya aktivitas enzim protease diharapkan dapat membantu mengoptimalkan penyerapan protein di pakan.

Enzim protease adalah enzim yang berperan dalam proses pencernaan protein dalam tubuh. Dalam sistem pencernaan ikan, protein dari pakan tidak langsung diserap tetapi didegradasi terlebih dahulu oleh enzim protease menjadi asam amino atau peptida kemudian diserap tubuh. Proses degradasi protein ini terjadi di lambung dan usus, sementara penyerapan makanan terjadi di usus (Fujaya, 2004). Selain untuk degradasi protein nutrien, protease juga diperlukan dalam sejumlah reaksi biokimia tubuh seperti mekanisme patogenisitas, proses koagulasi darah, proses sporulasi, diferensiasi, sejumlah proses pasca translasi protein, dan mekanisme ekspresi protein ekstra seluler (Rao et al., 1998).

Penelitian ini bertujuan untuk mendapatkan informasi awal tentang pencernaan protein di dalam sistem pencernaan ikan kerapu macan, khususnya kerja enzim protease setelah beberapa waktu pemberian pakan. Kondisi sisa pakan di lambung dan usus juga diamati.

\section{BAHAN DAN METODE}

\section{Pemilihan Ikan Uji}

Aktivitas enzim protease ditentukan oleh sifat substrat (protein) dan jenis enzim protease maupun kondisi lingkungan di mana reaksi enzimatis terjadi. Sifat enzim protease dapat berbeda tergantung organisme yang menghasilkannya. Sebagai gambaran ikan karnivora cenderung memiliki aktivitas enzim protease yang lebih tinggi dibanding ikan-ikan herbivora. Bahkan ikan-ikan 
yang berasal dari satu jenis, mungkin saja aktivitas enzim proteasenya berbeda karena berasal dari induk yang berbeda. Oleh karena itu, untuk melakukan analisis enzim protease perlu diperhatikan dengan baik tahapan penyiapan ikan uji dan pakan agar dapat mengurangi pengaruh dari faktor lain selain faktor yang diuji. Beberapa hal yang perlu diperhatikan di antaranya adalah asal ikan, keseragaman ukuran, dan kondisi pemeliharaan, serta jenis pakan yang diberikan. Penyiapan ikan uji diawali dengan seleksi (pemilihan) ikan yang didasari pada kesehatan, ukuran, umur, dan asal ikan. Ikan uji sebaiknya berukuran cukup besar agar jumlah enzim yang diperoleh cukup untuk pengujian. Untuk mengurangi pengaruh faktor genetis dan kondisi lingkungan lainnya dalam pengujian maka semua ikan uji sebaiknya berasal dari satu "cohort" dengan ukuran yang relatif seragam dan mendapat perlakuan yang sama.

\section{Penyiapan dan Pemberian Pakan}

Perbedaan perlakuan, seperti pemberian pakan serta kepadatan, akan mempengaruhi pertumbuhan dan perkembangan ikan. Hasil pengamatan di keramba jaring apung (KJA)-Teluk Awerange Kabupaten Barru, Sulawesi Selatan (milik Balai Riset Perikanan Budidaya Air Payau) menunjukkan adanya pertumbuhan yang lebih baik pada ikan-ikan yang dipelihara dalam keramba penelitian dibandingkan dengan ikan-ikan dalam bak penampungan nelayan yang memiliki tingkat kepadatan yang lebih tinggi serta kuantitas dan kualitas pakan yang tidak terkontrol baik.

Penyiapan dan pemberian pakan adalah tahap selanjutnya yang perlu diperhatikan. Semua ikan perlu diberi pakan yang sama serta disesuaikan dengan kebiasaan makannya. Untuk kerapu macan sebaiknya diberikan pakan moist pellet dengan kadar protein 45\%$50 \% \mathrm{Hal}$ ini didasari oleh pertimbangan hasil penelitian Balai Riset Perikanan Budidaya Air Payau (BRPBAP), Maros yang menunjukkan bahwa ikan kerapu macan lebih respon terhadap pakan moist pellet dibanding dry pellet dan kadar protein pakan terbaik untuk pemeliharaan ikan kerapu macan di KJA adalah 45\%-50\%(Gambar 1). Pertimbangan lainnya adalah ikan-ikan ini telah terbiasa (beradaptasi) dengan pakan moist pellet. Komposisi pakan moist pellet dapat dilihat pada Tabel 1. Pemberian pakan dengan kadar protein yang cukup tinggi dimaksudkan pula untuk mengoptimumkan produksi enzim protease. Pemberian pakan pada sore hari dimaksudkan agar ikan dapat menghasilkan cukup banyak enzim protease pada malam hari dan dapat diambil pada keesokan harinya. Pengambilan enzim protease dilakukan pada 12,15 , dan 18 jam setelah pemberian pakan.
Tabel 1. Formulasi pakan ikan kerapu macan

\begin{tabular}{lc}
\hline \multicolumn{1}{c}{ Bahan } & Kandungan (\%) \\
\hline Tepung ikan & 49,0 \\
lkan rucah (kadar air 75\%) & 50,0 \\
Dedak halus & 9,0 \\
Tepung terigu & 8,5 \\
Tepung kedelai & 7,0 \\
Tepung kepala udang & 8,0 \\
Minyak ikan lemuru & 2,0 \\
Minyak kedelai & 1,0 \\
Mineral mix & 1,0 \\
Vitamin mix & 2,0 \\
\hline
\end{tabular}

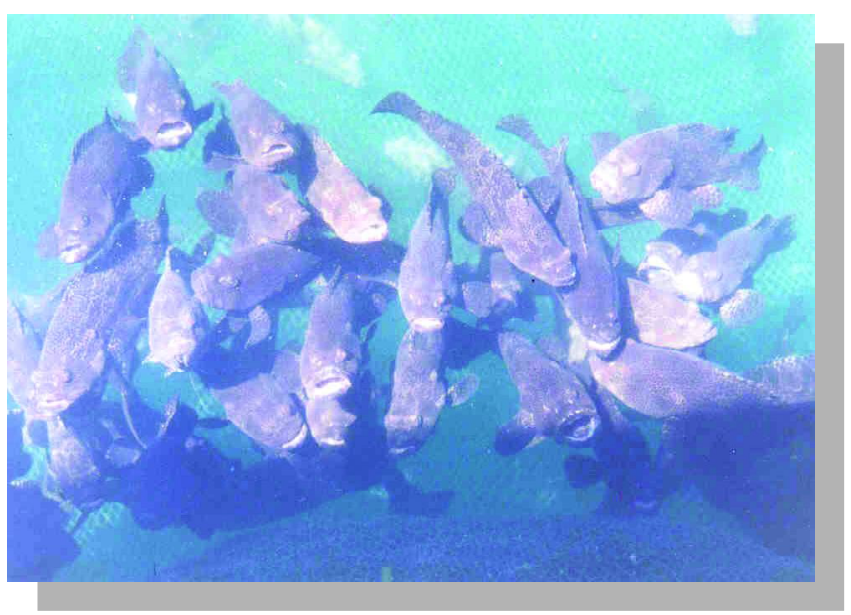

Gambar 1. Ikan kerapu macan di keramba jaring apung

\section{Pengambilan Enzim Protease}

Enzim protease diambil dari cairan lambung dan usus ikan kerapu macan. Isi lambung dan usus dimasukkan ke tabung (tube), selanjutnya disentrifuse dengan kecepatan $6.000 \mathrm{rpm}$ pada suhu $4^{\circ} \mathrm{C}$ selama 10 menit. Tujuan dari sentrifuse ini adalah untuk memisahkan antara padatan (sisa pakan) dan cairan (supernatan) yang mengandung enzim protease. Supernatan diambil dan dimasukkan kedalam tabung lainnya dan disimpan dalam refrigerator atau langsung dianalisis. Penyimpanan supernatan dilakukan pada suhu rendah $\left( \pm 4^{\circ} \mathrm{C}\right)$ agar aktivitas enzim tetap stabil dan enzim terhindar dari kerusakan baik akibat terdegradasi maupun terdenaturasi.

\section{Analisis Aktivitas Protease}

Aktivitas protease diukur secara kuantitatif dengan metode Bergmeyer (Bergmeyer et al., 1983) yang sudah dimodifikasi, menggunakan substrat casein hammarsten (2\%b/v). Dalam analisis ini digunakan tiga perlakuan yaitu blanko, standar, dan sampel. Sebanyak $50 \mu \mathrm{L}$ larutan enzim 
ditambahkan kedalam tabung eppendorf yang berisi $250 \mu \mathrm{L}$ kasein $2 \% \mathrm{~b} / \mathrm{v}$ dan $250 \mu \mathrm{L}$ bufer universal $20 \mathrm{mM}$ pH 11,0. Pada perlakuan blanko dan standar, enzim digantikan dengan akuades dan tirosin $5 \mathrm{mM}$.

Larutan tersebut diinkubasi pada suhu $50^{\circ} \mathrm{C}$ selama 10 menit (suhu dan waktu inkubasi optimum enzim). Reaksi hidrolisis dihentikan dengan cara penambahan $500 \mu \mathrm{L}$ TCA 0,14 M. Pada blanko dan standar ditambahkan $50 \mu \mathrm{L}$ larutan enzim, sedangkan pada sampel ditambahkan $50 \mu \mathrm{L}$ akuades. Selanjutnya larutan diinkubasi kembali pada suhu $37^{\circ} \mathrm{C}$ selama 10 menit, dilanjutkan dengan sentrifugasi pada kecepatan 5.000 rpm selama 10 menit.

Sebanyak $375 \mu \mathrm{L}$ supernatan ditambahkan kedalam tabung berisi $1,25 \mathrm{~mL} \mathrm{Na}_{2} \mathrm{CO}_{3} 0,4 \mathrm{M}$ dan $250 \mu \mathrm{L}$ pereaksi folin ciocalteau 2:1, lalu diinkubasi kembali pada suhu $37^{\circ} \mathrm{C}$ selama 20 menit. Absorbansi larutan diukur pada panjang gelombang $578 \mathrm{~nm}$. Satu unit aktivitas protease didefinisikan sebagai jumlah enzim yang dapat menghasilkan satu $\mu \mathrm{mol}$ produk tirosin per menit pada kondisi pengukuran. Aktivitas enzim dihitung berdasarkan persamaan berikut:

$$
\begin{gathered}
\text { Aktivitas protease }(\mu / \mathrm{mL})=Y \\
Y=\frac{\text { Abs Sampel - Abs Blanko }}{\text { Abs Standar - Abs Blanko }} \times \frac{\text { Faktor Pengenceran }}{\text { Waktu }}
\end{gathered}
$$

\section{HASIL DAN BAHASAN}

Hasil penelitian aktivitas enzim protease dari ikan kerapu macan berukuran \pm 500 gram baik di usus maupun di lambung pada beberapa waktu setelah pemberian pakan moist pellet dapat dilihat pada Gambar 2 dan Gambar 3. Hasil analisis aktivitas enzim protease usus menunjukkan adanya penurunan aktivitas dengan semakin lamanya waktu setelah pemberian pakan (Gambar 2). Pada saat 12 jam setelah makan (JSM) rata-rata aktivitas enzim protease sebesar 7,45 $\mu / \mathrm{mL}$. Pada 15JSM (3 jam kemudian) aktivitas enzim usus menjadi $6,08 \mu / \mathrm{mL}$ atau turun sebesar $18,41 \%$ dan setelah 18 JSM aktivitas enzim di usus tinggal tersisa $5,03 \mu / \mathrm{mL}$ atau berkurang $32,52 \%$

Hasil analisis enzim lambung juga menunjukkan penurunan aktivitas enzim protease dengan semakin lamanya waktu setelah pemberian pakan (Gambar 3). Pada 12 jam, rata-rata aktivitas enzim protease rata-rata sebesar 2,615 $\mu / \mathrm{mL}$. Pada $15 \mathrm{JSM}$, aktivitas enzim protease turun menjadi rata-rata sebesar $0,292 \mu / \mathrm{mL}$ dan pada saat $18 \mathrm{JSM}$, tidak ada lagi aktivitas enzim protease. Namun demikian, aktivitas pencernaan protein di dalam lambung lebih tinggi keragamannya dibanding pada usus, di mana dari dua sampel ikan yang diuji dalam 12 dan 15 JSM hanya satu yang ditemukan memiliki aktivitas enzim

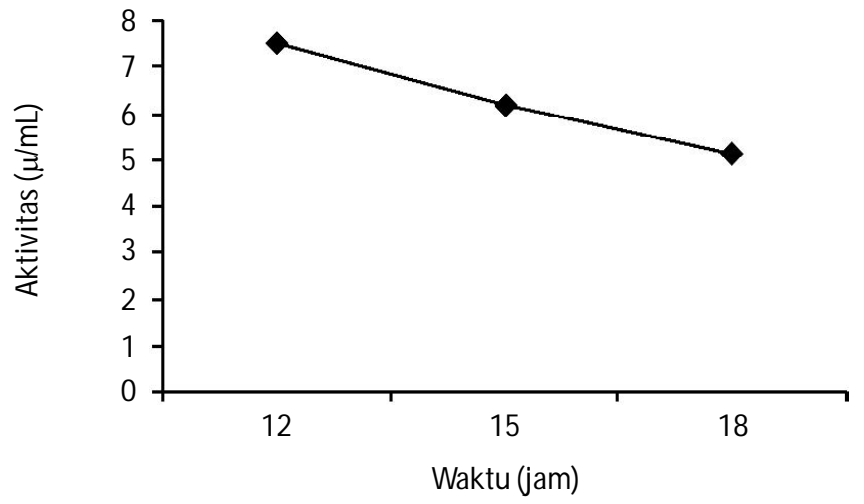

Gambar 2. Aktivitas enzim protease di usus ikan kerapu 12, 15, dan 18 jam setelah pemberian pakan

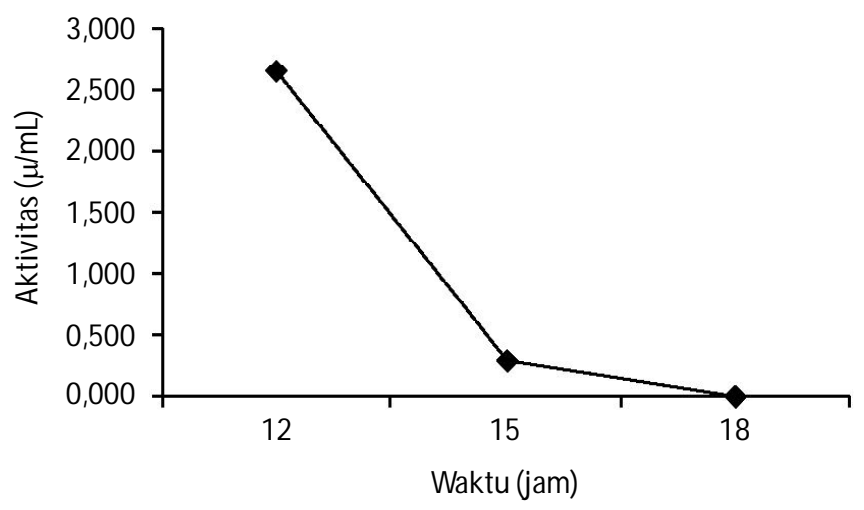

Gambar 3. Aktivitas enzim protease di lambung ikan kerapu setelah 12, 15, dan 18 jam setelah pemberian pakan

protease. Sementara pada 18 jam, tidak ditemukan adanya aktivitas enzim protease.

Pada 12 jam setelah pemberian pakan (saat pagi hari), usus ikan banyak mengandung cairan dan sedikit padatan (sisa pakan). Tingginya aktivitas protease di usus pada pagi hari nampaknya disebabkan oleh akumulasi produksi protease saat malam sementara masuknya padatan dari lambung ke usus masih berjalan lambat. Hal ini ditandai pula dengan masih penuhnya lambung ikan oleh pakan yang diberikan.

Pada 15 jam setelah pemberian pakan, dibanding dengan 12 jam setelah pemberian pakan, sisa pakan di lambung sudah mulai berkurang dan sisa pakan lebih banyak terdapat di usus. Di saat yang sama terjadi penurunan aktivitas enzim protase pada usus. Turunnya aktivitas enzim protease di usus pada 15 jam setelah pemberian pakan mungkin disebabkan oleh meningkatnya substrat yang masuk ke usus sementara enzim protease tidak cukup banyak diproduksi. Hal ini menyebabkan terjadinya penurunan konsentrasi protease dibandingkan pada saat 12 jam setelah pemberian pakan. Di samping 
itu penurunan aktivitas enzim ini juga dipengaruhi oleh lamanya reaksi enzim-substrat. Semakin lama reaksi enzim-substrat akan menyebabkan enzim kehilangan sebagian kemampuan proteolitiknya.

Sedangkan pada 18 jam setelah pemberian pakan, terlihat cairan dan sisa pakan di lambung sebagian besar sudah berkurang namun jumlahnya di usus masih cukup banyak walaupun tidak sebanyak dibanding pada saat 15 jam setelah pemberian pakan. Penurunan aktivitas enzim protease di usus ini mungkin disebabkan oleh produksi enzim protease yang sudah banyak berkurang sementara sebagian enzim yang ada telah rusak (terdenaturasi) akibat reaksi enzim-substrat yang telah terjadi cukup lama dan atau terbuangnya bersama feses pada akhir proses pencernaan.

Sementara penyebab tidak konsistennya aktivitas enzim pada lambung belum dapat dijelaskan. Beberapa hal yang mungkin menjadi penyebab adalah kesalahan sampling yang menyebabkan masuknya cairan usus yang mengandung protease ke lambung, penanganan sampel yang menyebabkan terganggunya aktivitas enzim atau kondisi reaksi enzimatis yang tidak optimum. Analisis enzim protease menggunakan $\mathrm{pH} 8$ (disamakan dengan aktivitas enzim usus), sementara $\mathrm{pH}$ optimum untuk aktivitas enzim di lambung ini mungkin lebih rendah. Kondisi lingkungan yang tidak optimum ini menyebabkan aktivitas enzim tidak bekerja maksimal. Menurut Fujaya (2004), enzim protease di lambung adalah enzim pepsin. Enzim ini aktif pada pH 2--4.

Secara umum enzim protease diproduksi oleh tubuh (pankreas) untuk mencerna protein dari pakan agar dapat diserap oleh sel-sel enterosit yang terdapat pada dinding sebelah dalam usus. Oleh protease, substrat protein didegradasi (digest) menjadi peptida dan selanjutnya menjadi asam amino. Perubahan aktivitas enzim usus pada selang waktu berbeda setelah pemberian pakan nampaknya disebabkan adanya perubahan kadar protease dan kondisi lingkungan di dalam usus. Di mana produksi enzim protease dari pankreas yang dikirim ke usus sangat dipengaruhi oleh protein dalam pakan. Protein pakan ini berperan sebagai aktivator bagi terekspresinya enzim protease pada sel-sel eksokrin pankreas yang akan disalurkan ke usus. Menurut Fujaya (2004), pankreas terdiri atas dua tipe sel yaitu sel eksokrin dan sel endokrin. Sel endokrin menyintesis hormon-hormon sementara sel eksokrin menyintesis enzim-enzim termasuk protease. Selanjutnya disampaikan bahwa pada kasus tidak ada enzim pankreas, maka hanya 50\%protein yang diserap dari total protein yang dikonsumsi.
Interaksi antara protein pakan dengan ekspresi protease mungkin disebabkan karena produksi protease dilakukan oleh enzim-enzim regulatorik. Enzim-enzim seperti ini tidak aktif secara terus-menerus tetapi dipengaruhi oleh adanya aktivator dan inhibitor, yang biasanya berupa substrat. Dalam hal ini substrat protein mungkin berperan sebagai aktivator. Semakin tinggi kadar protein di pakan maka produksi enzim protease akan meningkat dan sebaliknya akan menurun disaat substrat berkurang. Menurut Lehninger (1982), berdasarkan ekspresinya, enzim dibagi menjadi enzim pengatur (regulator enzyme) dan enzim terus-menerus (constitutive enzyme). Enzim regulator tidak mengekspresikan protein yang disandinya secara terusmenerus, tetapi dipengaruhi oleh adanya represor atau aktivator. Sementara enzim konstitutif mengekspresikan protein yang disandinya secara terus-menerus dan tidak dipengaruhi oleh adanya represor atau aktivator.

\section{KESIMPULAN}

Kesimpulan yang dapat diperoleh dari penelitian ini yaitu: semakin lama waktu setelah pemberian pakan, maka aktivitas enzim protease di usus semakin berkurang. Hal ini menandakan bahwa enzim protease di usus ikan kerapu macan tidak diproduksi secara terus-menerus tetapi tergantung pada kondisi pakan yang masuk kedalam sistem pencernaan.

\section{DAFTAR PUSTAKA}

Bergmeyer, H.U. and M. Grassl. 1983. Methods of enzymatic analysis. Vol. II Verlag Chemie, Weinhein. $539 \mathrm{pp}$.

Fujaya, Y. 2004. Fisiologi Ikan. Dasar Pengembangan dan Teknik Perikanan. Rineka Cipta. Jakarta. 179 pp.

Kabangnga, N., Burhanuddin, Usman, S. Lante, dan Kamaruddin. 2004. Kebutuhan optimum protein dan energi pakan pembesaran ikan kerapu macan di tambak. Laporan Hasil Penelitian. Balai Riset Perikanan Budidaya Air Payau, Maros. 10 pp.

Laining, A., Rachmansyah, T. Ahmad, and K. Williams. 2003a. Apparent digestibility of selected feed ingredients for humpback grouper, Cromileptes altivelis. Aquaculture. 218: 529-538.

Laining, A., N. Kabangnga, dan Usman. 2003b. Pengaruh protein pakan yang berbeda terhadap koefisien kecernaan nutrient serta performansi biologis kerapu macan (Epinephelus fuscoguttatus) dalam keramba jaring apung. J. Pen. Perik. Indonesia. 9(2): 29-34.

Lehninger, A.L. 1982. Principles of Biochemistry. Worth Publisher Inc. Alih bahasa, Maggy T. Suhartono. 369 pp. 
Rao, M.B., A.M. Tanksale, M.S. Ghatge, and V.V. Deshpande. 1998. Molecular and Biotechnological Aspects of Microbial Proteases. Microbiology and Molecular Biology Reviews, September 1998. p. 597635. 62(3): 1,092-2,172.
Usman dan N.N. Palinggi. 2005. Manajemen pemberian pakan. Makalah dipresentasikan pada kegiatan "sertifikasi bidang keahlian untuk staf pengajar bidang pertanian jurusan perikanan", tanggal 20-24 Juni 2005 di BRPBAP, Maros-Sulawesi Selatan. Balai Riset Perikanan Budidaya Air Payau, Maros. 14 pp. 